\title{
KNOWLEDGE SHARING MELALUI MOTIVASI BELAJAR DAN PELATIHAN BAHASA INGGRIS PADA YAYASAN DOMYADHU PAMULANG
}

\author{
${ }^{1 *}$ Arief Budi Santoso, ${ }^{2}$ Bachtiar Arifudin Husain, ${ }^{3}$ Gojali Supiandi, \\ ${ }^{4}$ Aden Prawiro Sudarso, ${ }^{5}$ Irfan Rizka Akbar \\ Universitas Pamulang \\ Email : 1ariefbudisantoso01@gmail.com
}

Manuskrip: Sept-2020; Ditinjau: Okt-2020; Diterima: Okt-2020; Online: Jan-2021; Diterbitkan: Jan-2021

\begin{abstract}
ABSTRAK
Pengabdian Kepada Masyarakat adalah salah satu Tri Dharma Perguruan Tinggi di Universitas Pamulang. Program ini bertujuan untuk mengembangkan potensi dosen dalam segi akademik dan Sosial terhadap masyarakat sekitar serta peran dan kontribusinya terhadap masyarakat. Knowledge Sharing sangat dibutuhkan oleh semua manusia dalam menggali informasi dan berbagi ilmu. Knowledge Sharing yang dilakukan adalah motivasi belajar dan juga pelatihan bahasa inggris secara online. Kegiatan di laksanakan pada Yayasan Domyadhu Pamulang dengan metode eksperimental studi dengan peserta 10 anak yatim beserta pengurusnya..
\end{abstract}

\section{Kata Kunci : Motivasi, Bahasa Inggris}

\section{PENDAHULUAN}

Anak yatim piatu membutuhkan uluran tangan dari masyarakat, maka dari itu pengembangan SDM dari mereka hams di tingkatkan agar mereka dapat meraih kesuksesan ketika lulus sekolah. Pendidikan dan program motivasi belajar dan pelatihan bahasa inggris sangat membantu mereka untuk mengerjakan segala aktivitas mereka, kegiatan ini memungkinkan mereka untuk mengembangkan keterampilan dan memori karena mereka bekerja keras untuk belajar mengatur waktu mereka agar lebih efisien dan lebih disiplin

Seluruh pelajar saat ini diharapkan mampu mengenal bahasa Inggris lebih dalam, mengapa karena setelah mereka lulus diharapkan mereka dapat memiliki kemampuan komunikasi yang baik salah satunya Bahasa inggris karena pasar pesaing Global sudah masuk. Di era global seperti sekarang ini, akan semakin banyak perkembangan yang terjadi di negeri ini. Mulai dari perdagangan bebas, semakin banyaknya berdiri perusahaan-perusahaan asing di indonesia sehingga penggunaan bahasa intemasonal seperti bahasa inggris sudah sangat tersebar luas, tentunya untuk para calon entrepreneur dan pencari kerja sudah menjadi suatu keharusan untuk bisa menguasai bahasa inggris agar bisa mengikuti perkembangan jaman di era globalisasi ini. Bahasa inggris adalah bahasa yang paling banyak 
digunakan di dunia. Bahasa ini merupakan bahasa ibu untuk lebih dari 400 juta orang diseluruh dunia. dalam setiap hari jutaan orang menggunakan bahasa inggris di tempat kerja maupun di kehidupan sosial. Ketika kepala pemerintahan bertemu, Bahasa inggris adalah bahasa yang paling sering digunakan. Dan ketika orangorang dari bangsa yang berbeda saling bertemu, bahasa inggris adalah satu-satunya bahasa penghubung yang digunakan oleh mereka.

Memasuki era globalisasi dan informasi, bangsa Indonesia dituntut mampu bersaing dengan bangsa-bangsa lain dalam berbagai bidang kehidupan. Dalam era tersebut, penguasaan ilmu pengetahuan dan teknologi menjadi suatu keharusan karena dapat menentukan kemampuan suatu bangsa untuk menang dalam persaingan. Keterkaitan global antar bangsa pada masa itu, juga menempatkan bahasa asing pada posisi yang sangat strategis.

\section{METODE PELAKSANAAN KEGIATAN}

Metode dalam pengabdian ini merupakan metode eksperimen kegiatan yang digunakan kepada peserta setelah diberikan pelatihan, selanjutnya mereka akan di berikam test guna mengetahui ke efektifan metode. Kegiatan pelatihan berisi antara lain ceramah, contoh dan tanya jawab. Kegiatan ini dilakukan melalui virtual conference menggunakan aplikasi zoom dikarenakan pandemic corona.

\section{HASIL DAN PEMBAHASAN}

Para pelajar membutuhkan bahasa Inggris karena merupakan United Nation untuk pemersatu atau Lingua Franca. Selain itu pelajar membutuhkan bahasa Inggris untuk melanjutkan studi dengan mengikuti test Toefl atau Ielts dan semua itu butuh persiapan yang matang. Dan setelah mereka lulus sekolah bahasa inggris merupakan persyaratan utama untuk di terimanya masuk kerja jika itu merupakan perusahaan asing atau perusahaan global.

Pengetahuan adalah hal yang sangat fundamental dalam organisasi karena pengetahuan memiliki hubungan yang sangat kuat dengan kesuksesan organisasi (Nonaka \& Takeuchi, 1995). Knowledge sharing adalah proses pemindahan keterampilan dan kemampuan antar karyawan (Lin, 2007). Hasil studi yang dilakukan oleh Jordan \& Jones (1997) mengatakan bahwa proses knowledge sharing berpengaruh pada kesuksesan dan keuntungan organisasi terutama dalam kepemilikan dan peningkatan modal intelektual dan kesuksesan organisasi.

Sementara itu, Pugna dan Boldeanu (2014) menyarankan bertukar modal pengetahuan di antara orang-orang dalam rangka meningkatkan kinerja karyawan dan meningkatkan manfaat dan kinerja organisasi. Hal ini mengandung makna bahwa knowledge sharing merupakan sumber daya terbesar bagi organisasi untuk meningkatkan kinerja dan mendapatkan keunggulan kompetitif berkelanjutan (Ndlela \& Toit, 2001; Lin, 2007; Wang, 2009). 


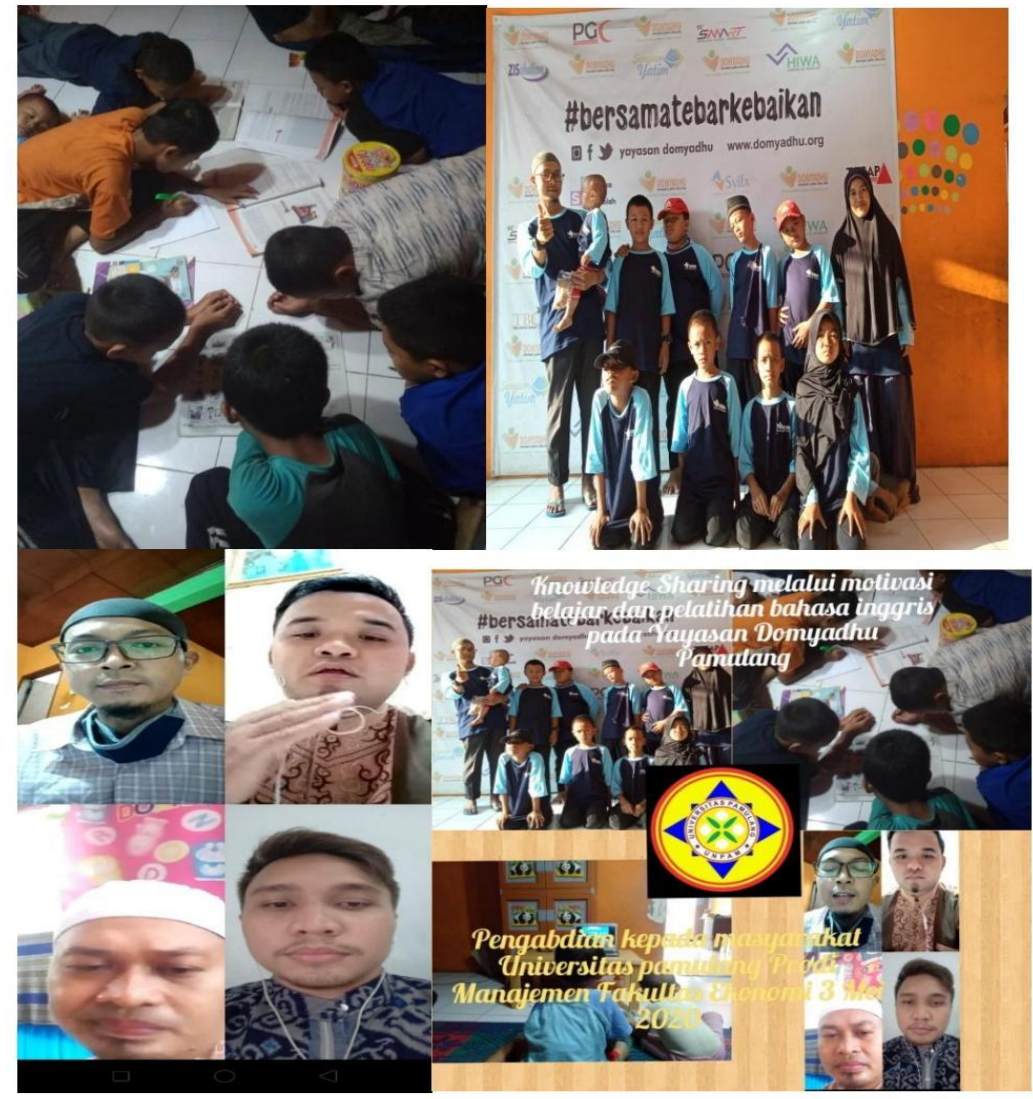

Gambar 1. Aktivitas selama PKM

Knowledge diciptakan secara terus-menerus, terjadi interaksi dinamis antara tacit knowledge dengan explicit knowledge (Nonaka, 1994; Nonaka et al, 2000, dalam Tseng, 2010). Jenis interaksi ini disebut knowledge Conversion atau SECI (socialization, externalization, combination, internalization). SECI model Nonaka dan Takeuchi menjelaskan terbentuknya knowledge baru karena adanya interaksi atau perubahan (konversi) antara dua jenis pengetahuan yakni tacit knowledge atau pengetahuan yang masih berada di dalam fikiran atau otak manusia dan explicit knowledge atau pengetahuan yang sudah direkam atau didokumentasikan. Melalui dua jenis pengetahuan itu, terjadi proses sosialisasi, ektemalisasi, kombinasi dan intemalisasi yang dinamakan sebagai knowledge spiral.

\section{KESIMPULAN DAN SARAN}

Di tengah pandemic virus Corona pada tahun ini pengabdian rnasyarakat ini sangat penting guna rnernbantu rnasyarakat urnurn, khususnya pelajar yang tinggal di asrarna dornyadhu parnulang. Dengan rnernberikan Sharing Knowledge rnelalui aplikasi online akan rnernbantu untuk rnernberikan sernangat dalarn belajar di asrama khususnya belajar bahasa Inggris. 


\section{DAFTAR PUSTAKA}

Afifuddin. (2013). Dasar Manajeemen. Alfabeta. Bandung

Arina Idzna Mardillah dan Kusdi Raharjo. (2017). Pengaruh Knowledge Sharing

Terhadap Kompetensi Individu dan Kinerja Karyawan. Jurnal Administrasi Bisnis (JAB) Vol.46 No.2

Bambang Setiarso. (2009). Penarapan Knowledge Management Pada Organisasi, Graha Ilmu, Yogyakarta.

Cheng M.Y, Ho J.S dan Lau P. M. (2011). Knowledge sharing in Academic Institutions: a Study of Multimedia University Malaysia. Electronic Journal of Knowledge Management, 7(3), 313-324.

Sofyan, S., Prasada, D., \& Akbar, I. R. (2020). Pengaruh Motivasi, Lingkungan Kerja dan Kepuasan Kerja Terhadap Kinerja Guru SMP/MTs Muhammadiyah Cabang Sawangan. Jurnal Ilmu Komputer dan Bisnis, Volume 11, Issue 2a, Pages 44-55

Sunarsi, D, et.al (2020). Menatap Wajah Pendidikan Indonesia Di Era 4.0: A Book Chapter of Indonesian Lecturer Associations. Kota Serang: Desanta Muliavisitama

Yuangga, K. D., Jasmani, J., \& Sunarsi, D. (2017). The Influence of Technology Determinism and Technology Literacy on Student Learning Outcomes (On MA Daarul Hikmah Pamulang). PINISI Discretion Review, 1(1), 23-30. 